\title{
Tin deposits at Přebuz and Rolava in the Krušné hory / Erzgebirge, Czech Republic: classic localities, new challenges
}

\author{
Cínová ložiska u Přebuzi a Rolavy v Krušných horách, \\ Česká republika: klasické lokality, nové výzvy
}

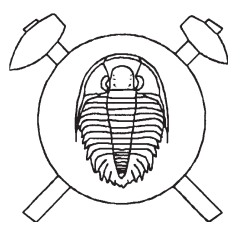

\author{
(3 figs) \\ PETR ROJÍK \\ Sokolovská uhelná, právní nástupce, a.s., Staré náměstí 69, 35600 Sokolov; rojik@suas.cz
}

\begin{abstract}
The Czech part of the late-Variscan Karlovy Vary (Eibenstock) pluton in the Krušné hory (Erzgebirge) Mts. was studied with a focus on the problems of greisen tin deposits and their relationship to highly evolved granites. The paper is based on the author's detailed field work and research of mining history. Important tin deposits of greisen type are concentrated to a girth of an oval shape ("tin ring") situated on the Czech territory roughly in the centre of the outcrops of the younger granite suite (YIC granite). Tin deposits are spatially associated with the youngest highly evolved granites. Greisen zones intersect all the known types of granites and converge towards the depth. Tin contents decline with depth and laterally to the centre of the "tin ring". Centres of greisen zones enclose veinlets of cassiterite, löllingite, microcline, quartz, and hematite whose depth extension is unknown. This supports the concept of a tectonic predisposition of ore mineralization and of a deep source of tin, related to the source of the late intrusions of highly evolved granites. Certain porphyritic granite textures exhibit bimodality of the groundmass reminding of two-phase granite textures developed under subvolcanic conditions. In places, a rhytmical layering (banding) of granites of the older and younger suite was observed.
\end{abstract}

Key words: Karlovy Vary pluton; Eibenstock pluton; Krušné hory; Erzgebirge; greisens; subvolcanic granites; layered granites

\section{Introduction}

The late-Variscan Karlovy Vary pluton (sensu Zoubek 1951, Vrána - Štědrá eds 1997) (synonyma Eibenstock pluton, Karlsbad-Eibenstock pluton, Nejdek massif, Nejdek-Eibenstock massif, etc.) is situated in the NW part of the Bohemian Massif in the border area between the Czech Republic and Germany. The pluton belongs to classic terrains where the differentiation of granites and their connection between highly evolved granites and tin deposits have been studied. In spite of a long history of research the field observations provide new findings previously not discussed in earlier papers.

According to the gravity field data the Karlovy Vary pluton is a laccolite 10-15 km thick (Šrámek - Mrlina 1997). The late orogenic and postorogenic intrusions of granitoids build two main suites: the Older Intrusive Complex (in further text OIC) or "Gebirgsgranit" (sensu Laube 1876) and the the Younger Intrusive Complex (further YIC) or "Erzgebirgsgranit" (sensu Laube 1876). Both the suites were first distinguished by Hochstetter (1856) in an almost forgotten publication about the Karlovy Vary area. From the metallogenetic point of view, the Hochstetter's "Zinngranit" has even a sharper definition than the Laube's "Erzgebirgsgranit" and modern Younger Intrusive Complex. Within the YIC granites Hochstetter (1856) distinguished between the older coarse-grained types of granite ("Hirschsprungsgranit") and the younger fine-grained tin-bearing types ("Zinngranit" or "Kreuzbergsgranit"). Similarly, the miners at Přebuz have observed that their mines provided better tin yields if situated in the areas of fine-grained granites (sine 1830) which form "lenses and stocks" (Reyer 1879).
A relatively high concentration of alkalis and water -rich fluids might have caused an anomalously high ascent of magmas to the upper crust. Along the Jáchymov-Gera deep-seated fault system of NW strike the roof of the granites lies in places about $600 \mathrm{~m}$ deeper. Abundant dykes of granite porphyries suggest the presence of a tectonically disturbed roof of intrusions. Hence the influence of a permeable roof on the escape of magmatic fluids and on the rate of the magma solidification can be documented.

\section{Granite textures in the Karlovy Vary pluton}

\subsection{Textures of subvolcanic granites}

The granites of both the intrusive complexes (OIC and YIC) often contain a substantial portion of a fine-grained matrix in their groundmass. Examples of the localities in the YIC area are Přebuz, Rolava, Chaloupky, Jelení, Nové Hamry (Fig. 1) and in the OIC area the quarries Mezihorská and Horní Rozmyšl on the southern slope of the Krušné hory Mts. All these granites exhibit the distribution of grains in four grain size groups distinguished as:

(1) phenocrysts

(2) \pm porphyroblasts

(3) medium-grained to coarse-grained groundmass

(4) fine-grained groundmass.

The fine-grained matrix attains commonly up to $25 \%$ of the entire groundmass in the "coarse-grained" and "medium-grained" granites, in places it can even prevail. The transition between various types of granites is gradational, often on the scales of dm. Thus, the use of textural terminology such as coarse-grained granite, finegrained granite, etc. seems to be rather meaningless when 

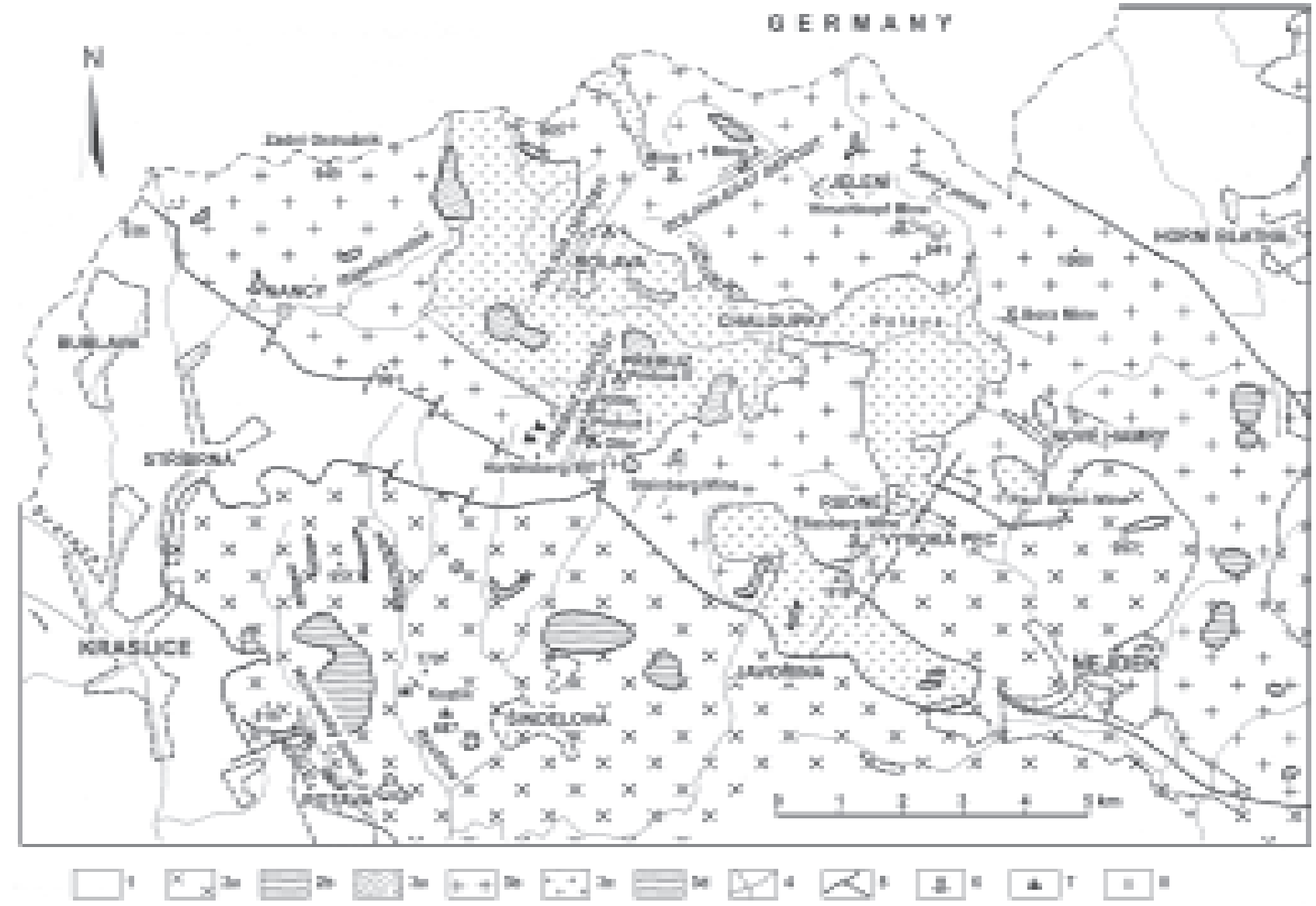

Fig. 1 Geological scheme of the Karlovy Vary pluton in the Czech part of the Krušné hory Mts. (using the geological map by Škvor - Sattran eds 1974). Explanation: 1 - Crystalline schists; 2 - Older Intrusive Complex (OIC): 2a - Porphyritic "medium-grained" biotite granites; 2b - Finegrained muscovite-biotite granites; 3 - Younger Intrusive Complex (YIC): 3 a - Porphyritic fine-grained biotite granites with bimodal groundmass; 3b - Porphyritic and porphyroblastic "coarse-grained" biotite granites often with bimodal groundmass; 3c - Porphyritic "medium-grained" muscovite-biotite granites, in places with bimodal groundmass; 3d - Fine-grained muscovite-biotite granites; 4 - Greisens; 5 - Faults; 6 - Abandoned mines; 7 - Outcrops (related to the text); 8 - Alluvial blocks (related to the text).

applied to the granites of the Karlovy Vary (Eibenstock) pluton. The fine-grained matrix is often concentrated in diffuse schlieren like in the YIC area at Nancy (Fig. 1) and Karlovy Vary (Brewery cellars) and in the OIC area at Loket. In the outcrops of the Bystrina valley near Rotava (OIC, Fig. 1) the author observed fine-grained diffuse schlieren, shaped en-echelon, which gradually passed into sills of aplitic granite. The residual magmatic melts in both OIC and YIC complexes injected partly solidified granites and formed leucocratic sills, blind dykes, blind stocks and balloon-shaped segregations.

The granites from the above-mentioned localities have typical porphyritic textures. The phenocrysts are formed by all the main rock-forming minerals (perthitic K-feldspars, albite-oligoclase, corroded bipyramidal quartz, mica) as also observed by Zoubek (1978) in Karlovy Vary. The textures of some granites in the Karlovy Vary pluton are similar to those of granite porphyries or even rhyolites (Fig. 2a).

Fig. 2

a - Subvolcanic granite with magmatically corroded phenocrysts of quartz and feldspars in the main YIC intrusion. Nancy, Rájecký potok valley, proluvium.

b - Boundary between the pegmatitic granite of the main intrusion of YIC (right) and the xenolite (?) of a subvolcanic granite (left). Přebuz Hartelsberg, northern slope, outcrop.

c - Penetrating crystals of fluorapatite (13 mm in size) in a cavity of pegmatitic granite in the main YIC intrusion. Přebuz, Otto Mine, dump.

d - Topaz crystal ( $8 \mathrm{~mm}$ in size) in a cavity of pegmatitic granite of the main YIC intrusion. Přebuz, Mine Přebuz I, dump.

e - Rhytmic layering in a dyke of the fine-grained YIC granite (width of the sample $55 \mathrm{~mm}$ ). Deposit Rolava - East, Mine 2, dump.

$\mathrm{f}-$ Rhytmic layering in a dyke of the fine-grained YIC granite (size of the sample $30 \times 20 \mathrm{~cm}$ ). $2 \mathrm{~km}$ SE of Jelení, Černý potok, alluvium.

g - Rhytmic layering of granite of the main YIC intrusion. Přebuz - Hartelsberg, NW slope, outcrop.

$\mathrm{h}$-Composite aplite-tourmalinite vein (width $3 \mathrm{~cm}$ ) in the main OIC intrusion. Horní Rozmyšl quarry. 

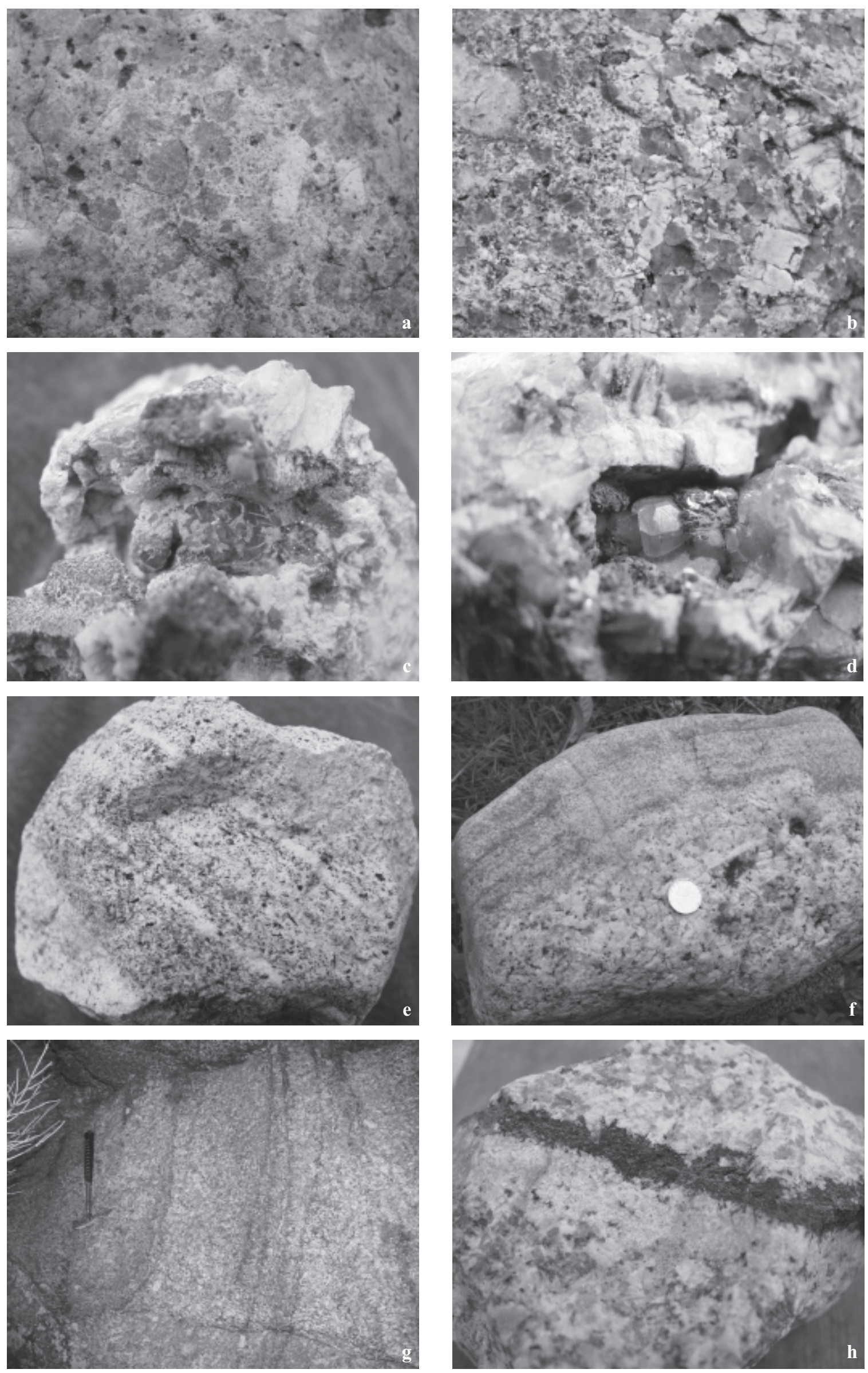
In an outcrop on the northern slope of the Hartelsberg hill near Přebuz (Fig. 1) a granite with a pronounced subvolcanic texture forms a sharply-circumscribed ballshaped enclave several meters in size in a pegmatitic granite of YIC (Fig. 2b).

If the phenocrysts and porphyroblasts prevail in the rock, which is relatively often, especially in the broad endocontact zone of YIC granites, the rock texture reminds of a pegmatite or stockscheider. Their miarolititic cavities contain automorphic crystals of fluorapatite (Fig. 2c), topaz (Fig. 2d), fluorite, quartz, microcline, calcite, dolomite, and Ba-pharmacosiderite, identified by means of X-ray diffraction analysis.

A possible subvolcanic character of the granites in Karlovy Vary area was first pointed out by Zoubek (1978). The so-called two-phase granites, first described from Malaysia, have been found at Doubí near Karlovy Vary and other localities in YIC granites (Seltmann - Štemprok 1994). Similar textures were observed by the author in the Smrčiny (Fichtelgebirge) pluton in the granites of Kösseine, Kerngranit or G3K (Hecht et al. 1997) but they have not yet been studied from this point of view.

Specific textures of granites in the Karlovy Vary pluton can be interpreted as a consequence of a high geothermal gradient during decompression and crystallization of granitic melts. This situation could have occurred if volatile-rich melts were intruded anomallously high in the preheated Earth crust. The textures of some granites in the Karlovy Vary pluton remind the texture of Cenozoic granophyres in originally shallow, now exhumed magmatic reservoirs of Iceland, under the conditions of a geothermal gradient of $5-10 \mathrm{~m} / 1^{\circ}$ (Gudmundsson Kjartansson 1996).

\subsection{Layered granites}

Some sills of leucocratic granitoids of the Karlovy Vary pluton exhibit rhytmic changes in the grain size and textures, from fine-grained aplitic to coarse-grained pegmatitic portions. The granites differring in grain-size in subparallel bands (layers) several $\mathrm{cm}$ wide, rhytmically repeating, with diffuse boundaries have been examined in the YIC area (Fig. 1) at Bublava (alluvium of the Stríbrný potok valley, E of the elevation 936), Strúbrná (proluvium W of the elevation 991), Nancy (alluvium of the Rájecký potok valley), the dump of the tin Mine $2 \mathrm{NW}$ of Jelení (Fig. 2e); alluvium of the creek Černý potok SE of Jelení (Fig. 2f). In the two latter localities blocks of a coarsegrained YIC granite were intersected by dykes of finegrained granites which exhibit a rhytmically layered texture, revealed by colour changes due to variation in the dark mica content. Breiter (2002) in the Podlesí granite stock near Horní Blatná (east of the area studied here), explained similar textures by unmixing of magmatic fluid phase whenever the vapour pressure opened fissures in the overlying solidified granite. This resulted in a repetitive state of phase disequilibrium. A similar stratification to that near Jelení has been found also near Rotava (Fig. 1), in the aplitic OIC granite and in the composite aplite/pegmatite sill in the medium-grained OIC granite in the outcrop in the Bystrina valley.

Also a stratified blind dyke of aplitic YIC granite near Přebuz on the NW-slope of Hartelsberg (987 m) was observed. Its layering is parallel to the margin of the dyke. At Hartelsberg layering in the main intrusion of "coarsegrained" porphyroblastic YIC granites was observed for the first time. The curved layers suggest occurrence of three-dimensional "cells" several metres in size. Layers of "coarse-grained" granite, dm-wide, with porphyroblasts of K-feldspar periodically alternate with $\mathrm{cm}$-thick layers of medium-grained biotite granite. Selectively weathered textures are shown in Fig. 2 g. Layered granites of the main YIC intrusion are also exposed east of Horní Blatná in the Wolfgang Mine (Vlčí jáma), where three-dimensional cells of granite contain discontinuous hull-shaped segregations of predominant quartz.

In the Mezihorská quarry (OIC) medium-grained granites are in places interleaved by sets of pararel layers of melanocratic granites. The dark stripes are discontinous, convex, $\mathrm{mm}$ to $\mathrm{cm}$ wide, with diffuse margins. They show no relation to the granite tectonic structure and are not accompanied by jointing systems.

All the mentioned curved rhytmic heterogenities of granites suggest magmatic circulating cells several meters to tens of meters large, possibly induced by a resorption of sunken blocks from the envelope rocks.

\subsection{Leucocratic nodules}

Leucocratic aplite/pegmatite magmatic nodules, often with tourmaline, are ball-shaped, $\mathrm{cm}-\mathrm{dm}$ in size and have relatively diffuse margins. They occur frequently in the main intrusion of OIC granites and exhibit a grainsize bimodality. The fine-grained fraction builds the matrix of coarse-grained sections. Phenocrysts of K-feldspars predominate in the centre of some nodules. In the medium-grained OIC granite in the Bystrina valley near Rotava a pegmatite nodule occurred at the termination of an aplite sill. At the same locality a balloon-shaped nodule of a coarse-grained quartz was found, stalky narrowed down, without any apparent vein continuation. Similar blind forms also exhibit some bodies of aplitic granites of YIC, e.g. Hartelsberg near Přebuz.

Quartz-tourmaline nodules are abundant in the late intrusions of OIC and in all the YIC granite types. They are ball-shaped, with relatively sharp boundaries ranging up to $130 \mathrm{~cm}$ in diameter, the largest being rimmed by a pink pegmatitic granite. Nowhere in the YIC area a veincontrolled passage or boron transport have been found. Therefore, the nodules possibly represent the relics of a stage of magma boiling.

In the contrary to $\mathrm{YIC}$, in the main OIC intrusion tourmaline with the composition of dravite-schorl (unpubl. X-ray diffraction analysis by M. Rehoř) very often occurs in veins. It builds radial aggregates in the fissures and joints of many granite, aplite and pegmatite 
outcrops (e.g. at Rotava, Mezihorská, Horní Rozmyšl Fig. 2h, Královské Poříčí and Těšovice in the Sokolov Basin). Tourmaline occurs also in the centre of crossing diffuse pegmatitic dykes composed almost exclusively of twinned phenocrysts of orthoclase (quarry Mezihorská) and in the pegmatite dykes (Smolné Pece S of Nejdek).

All granites rich in quartz-tourmaline nodules have a tendency to build discordant diffuse zones of E-W strike. For example, the zone Gottesberg - Bublava - Jelení Zlatý Kopec intersects all granite types (YIC). Tourmaline participates in an important way in the composition of greisens in the endocontact zone (Gottesberg, Horní Blatná). The tourmaline-quartz hornfelses intersected by secondary veins of tourmalinite occur in the exocontact zone, in the vicinity of the SW contact at Boda/Gottesberg, Brunndöbra; close to the NE contact at Potůčky and Zlatý Kopec. The W-E strike of tourmaline accumulations corresponds with the dominant structural trend of crystalline rocks.

\section{Greisens}

\subsection{Distribution of greisens}

A large majority of Sn-greisens is situated within YIC granites (or in their vicinity), which postdate the main intrusion of porphyritic "coarse-grained" biotite granite (Fig. 1). In the emplacement of the YIC granites, there is a well-visible tendency of granitic melts to a repeated use of identical SE-NW striking ascent routes (feeding channels). Reyer (1879) was the first who highlighted this fact. In the present erosion level the latest YIC granites build an elongated SE-NW striking body (Fig. 1).

The most important tin deposits of the area, i.e. the Přebuz, Rolava and Rolava - East deposits, follow the girth of this oval shape. They build together a "tin arch" (Janečka et al. 1969). On the basis of research of mining history and field studies (Rojík 2000) it is even possible to apply the term "tin ring". The girth is marked by the historical tin deposits (clockwise) Prrebuz, Rolava, Rolava - East, Jelení - Hirschkopf, Jelení - Bora, Nové Hamry - Paul-Bären Mine, Rudné/Javořina - Eliasberg, Přebuz - Steinberg (Fig. 1). Laterally, toward the center of the "tin ring", tin contents in greisens substantially decrease and the depth of mineable greisens decreases as it has been documentated in the Přebuz deposit (Kušnír Grotz 1959). In the centre of the "tin ring", in the vicinity of the former village Chaloupky (Neuhaus), traces of an unsuccessful mining mark the occurrence of (almost) sterile quartz greisens. That means that either the fluids escaped through the permeable roof of the pluton, or the greisens were deeper eroded. The first explanation seems to be more likely due to the abundance of skarn xenoliths and "tin-bearing garnets" in placers reported in the 18 th and 19th century. Beside the "tin ring", several isolated stocks of fine-grained granites and tin-bearing greisens (e.g. Zinnknock E of Nejdek, Vysoká Štola, Oldři- chov, Hroznětín) occur in the continuation of the SE-striking zone along the axis of YIC granites.

The greisens in the area studied crosscut all the granite types including the youngest aplitic stocks and sills (Fig. 1). The ore mineralization seldom overcrosses the exocontact zone of the granite (e.g. the Přebuz deposit mine adit on the SW slope of Hartelsberg hill). The greisens allways form reaction rims. Lamprophyres have not yet been found there.

The joint occurrence of the Sn-greisens in association with highly evolved Sn-granites refers to their possible common deep resource.

\subsection{Form of the greisen deposits}

Tin deposits in the Czech part of the Karlovy Vary pluton in the Krušné hory (Erzgebirge) Mts. consist of almost parallel greisen bands occurring in groups which follow subvertical, short, vicarized joints (Fig. 3a). The joint sets are up to $4.5 \mathrm{~km}$ long (Přebuz and Javořina/ Rudné, if considering all the known historical mines) and up to $350 \mathrm{~m}$ broad (Fig. 1). The deposits are segmented into pararell-packed zones ("Trümerzonen"), which were the object of mining from 1340 to 1958 (Rojík 2000).

A characteristic feature of the greisen bands is their convergence to the depth similarly to the Ehrenfriedersdorf tin deposit in Germany (Baumann et al. 2000). This fact has been recorded in the deposits Přebuz (Michler 1940, Škvor 1960), Rolava - East (mining maps of the company Zinnbergbau Sudetenland from 1941-1945, Kratochvíl 1946) and in the Paul-Bären Mine near Nové Hamry (Vogel 1872) (Fig. 1).

The mining of greisens never reached the depth below the level $-120 \mathrm{~m}$. Under this depth tin contents in the greisens were rapidly lowered. The greisens were in centres mineralized by veinlets with cassiterite, which continued to an unknown depth. In the veinlets extraordinary high metal contents have been revealed by mine exploration and drillings, e.g., at Přebuz $13.0 \% \mathrm{Sn}$ in the depth of $-135 \mathrm{~m}$ (Doležal 1957) and at Rolava - East where extractable tin contents reached even a depth of $385 \mathrm{~m}$ (Janečka et al. 1973).

All the historical Sn-deposits exhibit a single dominant strike of greisen bands. Besides, in all the deposits also indistinctive perpendicular joint greisens cross the dominant greisen bands in an oblique or perpendicular direction, without any visible dislocation (Fig. 3b). At these intersections, greisens were very richly mineralized (e.g. the Hirschkopf mine near Jelení and Eliasberg mine near Rudné).

In places greisens are intensively brecciated, especially at Přebuz (Michler 1940). Here, the greisens in the ore dump from the period of 1953-1958 are often phyllonitized, with addition of hematite (Fig. 3c). Also the samples taken from central strings of greisen deposits were often strongly jointed. Along the fissures, microcline was replaced by hematite. Löllingite was replaced by arsenopyrite (Grießmann - Schönherr 2005). 

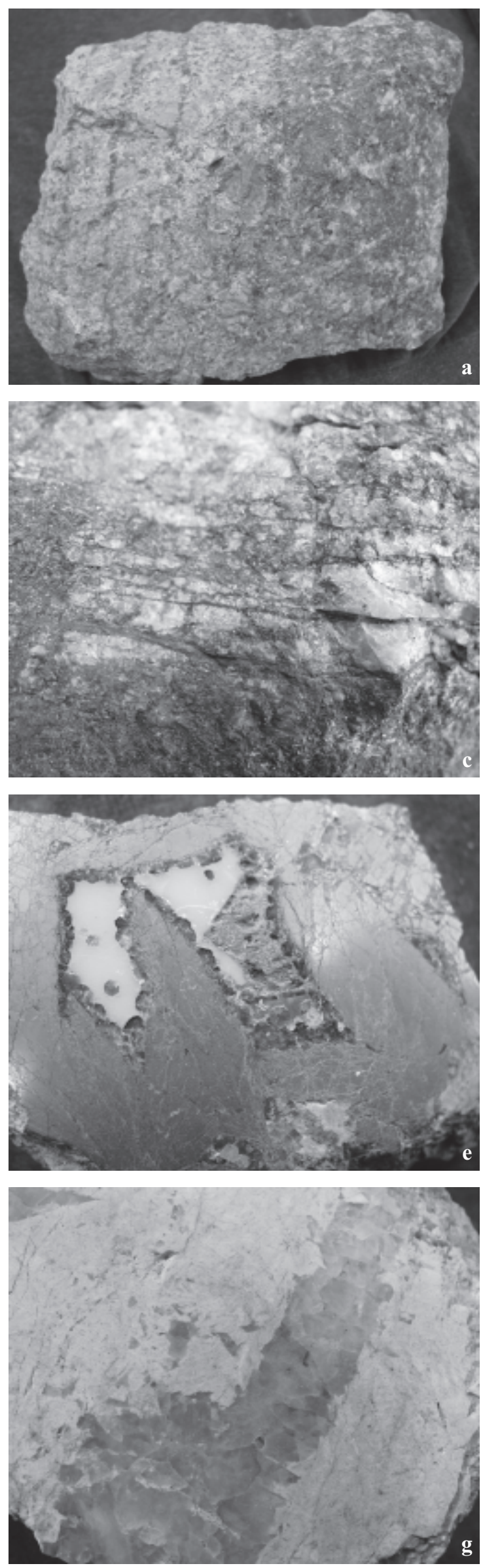
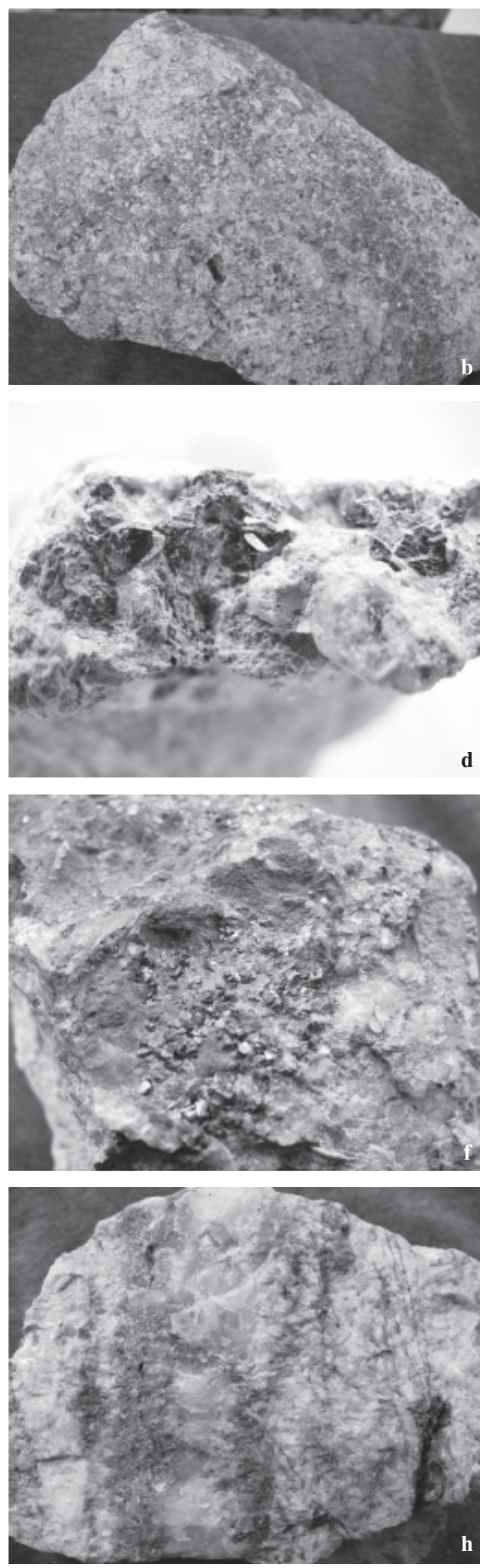
The form of greisen deposits in the studied area and the connection between Sn-greisens and Sn-granites support the importance of a tectonic control for the ore mineralization and suggest its deep source. Therefore, the author prefers the model presented recently by Štemprok (2003) who highlighted deep-seated magmatic sources active along steep and deep fault zones where the separation of melts, fluids and metal-rich volatiles occurred. Ore - bearing granite magmas prepared the way for the passage of magmatic and mantle fluids.

\section{Veins associated with greisens}

\section{1. "Cassiterite strings" (“Graupenschnüren”)}

This term (Putzer 1952, Baumann et al. 2000) denotes coarse-grained aggregates of cassiterite like "strings (lines) of cassiterite" in central fissures of greisens. The "Graupenschnüren" were described in situ at the lower levels of the Otto and Main mines in Přebuz (depth to 120 m) (Michler 1940, Putzer 1952). They are abundant in the dump material from the Přebuz I Mine (former Main Mine) from 1953 to 1958 when the deepest exploration levels reached a depth of $-180 \mathrm{~m}$. Cassiterite strings contain abundant cassiterite, wolframite, löllingite, arsenopyrite, topaz, sericite, gilbertite, occasionally also fluorite, pyrite, and rare feldspar. The "Graupenschnüren" are always rimed by a greisen with diffuse margins. They originated contemporarily with greisens, along slightly dilated joints.

\subsection{Veinlets with cassiterite, hematite and K-feldspar}

Veins between greisen bands at Přebuz have mineral assemblage similar to that of cassiterite strings. The veins contain cassiterite, löllingite, arsenopyrite, wolframite, quartz, topaz, fluorite, hematite, and muscovite (Fig. 3d, $3 \mathrm{e})$. The veins attain a maximum width of $6 \mathrm{~cm}$. According to mineral assemblage and diffuse margins the veins have likely a similar age as surrounding greisens. They originated by a more significant dilation of the fissure walls than in cassiterite strings. Michler (1940) noticed that the veins are blind and onset toward the deeper mine levels. This corresponds with the occurrence of vein fragments in the dump from 1953-1958.

The veinlets, "Graupenschnüren" and greisens alltogether represent an economic ore mineralization exploited during the World War II with the production of Sn and As concentrates (Rojík 2000). Among the As-minerals löllingite (Michler 1940) prevails over arsenopyrite and secondary minerals scorodite, arsenolite, arsenolamprite? (unpubl. X-ray diffraction analyses by J. Ševců) and segnitite? (unpubl. X-ray diffraction analysis by M. Řehoř). The fractured löllingite (Fig. 3e) was replaced by arsenopyrite (Grießmann - Schönherr 2005).

The veins rich in $\mathrm{Sn}$ and As minerals overlap in time with the origin of veinlets with K-feldspar and hematite. A cassiterite and feldspar vein was first observed at Přebuz (sine 1830). At the Rolava - East deposit, veinlets composed of cassiterite, hematitized K-feldspar and quartz surrounded by almost barren greisen were found in a depth under $300 \mathrm{~m}$ (Absolonová et al. 1966). But obviously they occur above the exploration mine level $-180 \mathrm{~m}$ because they were found by the author in the dump material of the Mines 1 and 2 from the mining and exploration period of 1941-1945 (Fig. 3f).

The veinlets of K-feldspar are abundant in the studied region. Their debris were found in proluvia and dumps (Přebuz - Mine II, Rolava East - Mine 2, Jelení - vicinity of the Hirschkopf Mine, Rudné - vicinity of the Eliasberg Mine, Javořina - SW slope of the elevation 919, Chaloupky village, and Zadní Ostružník hill). The veins consist of a pink microcline and white quartz in strongly variable proportion (Fig. $3 \mathrm{~g}$ ) whereby microcline appears to be often older then quartz. Microcline is often cracked and in places replaced by hematite. Veinlets of microcline and quartz attain a maximum width of $12 \mathrm{~cm}$ and always occur between mineralized or barren greisen bands. The "feldspar vein" in the Paul-Bären Mine near Nové Hamry (Vogel 1870) and an oblique vein of cassiterite and feldspar in Přebuz (sine 1830) probably crossed the greisens.

The feldspar veinlets have relatively sharp margins and are younger than greisenization. They originated by a subsequent dilation of the central fissure between the greisen bands. The feldspar veinlets originated likely from alkaline solutions ascending from the depth (late microclinization sensu Beus - Zalaškova 1962).

Some veinlets of feldspar and cassiterite in the Rolava - East deposit contain substantial amount of hematite (Absolonová et al. 1966). In the debris from the dumps of the Rolava 2, Přebuz I, II and Otto mines hematite was observed to be always younger than cassiterite (Fig. 3f) and also younger than microcline. The greisens were very

\section{饮}

Fig. 3

a - Parallel bands of tin-bearing quartz greisen (size of the sample $18 \times 15 \mathrm{~cm}$ ). Přebuz, mine Přebuz I, dump.

b - Perpendicular crossing of greisens bands. Mine Přebuz I, dump.

c - Phyllonitized greisen with secondary hematite. Mine Přebuz I, dump.

d - Veinlets of cassiterite, topaz, and gilbertite. Mine Přebuz I, dump.

e -Veinlets of löllingite, topaz, and gilbertite (polished section). Mine Přebuz I, dump.

$\mathrm{f}$-Veinlet of cassiterite (crystals $2 \mathrm{~mm}$ in size) and of younger hematite. Deposit Rolava - East, Mine 2, dump.

$\mathrm{g}-$ Veinlets of microcline and quartz (polished section, size $11 \times 7 \mathrm{~cm}$ ). Jelení, near the Hirschkopf Mine, erosion furrow.

$\mathrm{h}$ - Microcline veinlet partly replaced by younger greisenization (?). Deposit Rolava - East, Mine 2 , dump (size of the sample $9 \times 6 \mathrm{~cm}$ ). 
often interlayered by (sub) parallel monomineral veinlets of hematite (Mine 2 near Rolava, mines Přebuz I, II and Ritter) (Fig. 3c). In places, massive hematitization of surrounding greisens and granites took place. In some greisens from the Mine 2 near Rolava hematite represented even the dominant part. Here, during the World War II the dressing plant was scheduled to produce Fe concentrate (Rojík 2000).

In the Přebuz and Rolava - East deposits a simultaneous transport of iron (hematite) and uranium (torbernite, nováčekite, metazeunerite) was recorded.

\section{Conclusions}

Some porphyritic granites of the Karlovy Vary (Eibenstock) pluton in the Czech part of the Krušné hory (Erzgebirge) Mts. exhibit specific textures characterized by the grain-size bimodality of the groundmass and the presence of corroded bipyramidal phenocrysts of quartz. These features likely indicate emplacement of granitic melts into a subvolcanic level and their fast solidification.

Some OIC and YIC granites show in places a rhytmic diffuse layering manifested by alternating of layers, which differ in their grain size, colour, light/dark minerals proportion and selective weathering of some bands. The layering in the late intrusions of leucocratic aplitic granites is evenly shaped and strikes parallel with the sill and dyke contures. The layering of granites of the main intrusions is less regular and hull-shaped. Both types of layering originated in the magmatic stage. The former could be caused by periodic unmixing of magmatic fluid phase in the course of injection of vapour-rich melt into solidified granites. The latter may be connected with magmatic circulating cells in the vicinity of contact, possibly induced by the resorption of sunken blocks of the envelope rocks.

A spatial relationship between the granites, which postdate the main intrusion of the YIC granites, and the greisen deposits exist in the studied area. The latest YIC granites tend to build an oval-shaped, slightly elongated, SE-NW striking body. Tin-bearing greisens follow the girth of this oval shape and build altogether a "tin ring". Laterally, toward the center of the "tin ring", tin contents in greisens decrease and the depth of mineable greisens decreases as well. New evidences of the deep source of Sn-mineralization are indicated by: (1) the convergence of greisen bands to the depth, (2) the repeated tectonic faulting and mineralization of greisens, (3) the occurrence of blind veinlets in between the greisens bands, with three types of mineralization. The oldest veins contain cassiterite, löllingite, wolframite, and topaz. They are followed by the veins of microcline and quartz and finally by veinlets of hematite with a slight U-mineralization.

The form of greisen deposits and the joint occurrence of greisens and highly evolved granites support the importance of a tectonic control of the ore mineralization and suggest a common deep source for Sn-granites and Sn-greisens.
Acknowledgments. Author is thankful the reviewers for critical reading, improvement and linguistic correction of the manuscript. Many thanks are due to Prof. M. Štemprok and Dr. K. Breiter for the consultation as well as to Dr. J. Ševců and Dr. M. Řehoř for the X-ray diffraction analyses of some minerals.

Submitted February 20, 2006

\section{References}

Absolonová, E. - Janečka, J. - Kušnír, I. (1966): Zpráva o výzkumu ložisek Sn-rud v oblasti Rolava - Přebuz v letech 1964-1965. - MS ÚÚG Praha (Archiv ČGS P 60.1965).

Baumann, L. - Kuschka, E. - Seifert, T. (2000): Lagerstätten des Erzgebirges. - Stuttgart, $300 \mathrm{pp}$.

Beus, A. A. -Zalaškova, N. E. (1962): O processach vysokotemperaturnogo poslemagmatičeskogo metasomatoza $\mathrm{v}$ granitoidach (High-temperature postmagmatic metasomatic processes in granitoids). - Izvestija Akad. Nauk SSSR, Ser. Geol., 4, Moskva.

Breiter, K. (2002): From explosive breccia to unidirectional solidification textures: magmatic evolution of a P-and F-rich granite system (Podlesí, Krušné hory Mts., Czech Republic). - Bull. Czech Geol. Survey, Vol. 77, No. 2, 67-92, Praha.

Doležal (1957): Studie ložiska Přebuz. - MS Státní ústav pro projektování rudných dolů, Praha (Geofond P 9478/1).

Grießmann, M. - Schönherr, S. (2005): Kartierbericht. Spezialkartierung Přebuz-Rolava-Jelení (CZ). - MS Bergakademie Freiberg, 56 pp.

Guđmundsson, A. T. - Kjartansson, H. (1996): Land im Werden. Ein Abriß der Geologie Islands. - Reykjavik, 166 pp.

Hecht, L. - Vigneresse, J. L. - Morteani, G. (1997): Constraints on the origin of zonation of the granite complexes in the Fichtelgebirge (Germany and Czech Republic): evidence from a gravity and geochemical study. - Geol. Rundschau, 86, 93-109, Springer, Berlin.

Hochstetter, F. (1856): Karlsbad, seine geognostischen Verhältnisse und seine Quellen. - Karlsbad, Wien, 104 pp.

Janečka, J. - Absolonová, E. - Ďuriš, M. - Pavli̊, D. - Tenčík, I. (1969): Geologicko ložiskový výzkum Sn-W ložisek Českého masivu. - MS ÚÚG Praha (Geofond P 21490).

Janečka, J. - Štemprok, M. - Jarchovský, T. - Pavlio, D. - Strnad, J. Roos, E. - Absolonová, E. - Lomozová, V. - Bernard, J. - Píšová, J. -Maňour, J. - Klomínský, J. (1973): Závěrečná zpráva o geologickoložiskovém výzkumu Sn-W ložisek Českého masívu. - MS ÚÚG Praha (Geofond P 116.1973).

Kratochvíl, F. (1946): Zpráva o geologické prohlídce cínových dolů v Sauersacku u Přebuze. - MS SGÚ Praha (Geofond P 296).

Kušnír, I. - Grotz, K. (1959): Závěrečná zpráva o geologickém průzkumu na lokalitě Přebuz II. - MS GP Stř́ibro (Geofond FZ 3466).

Laube, G. C. (1876): Geologie des böhmischen Erzgebirges, I. Theil, Prag, $208 \mathrm{pp}$.

Michler, W. (1940): Die montangeologischen Verhältnisse des Zinnvorkommens von Frühbuß, Sudetengau. - MS Diplomarbeit Bergakademie Freiberg, 64 pp.

Putzer, H. (1952): Die Zinnerz-Lagerstätte von Frühbuss. - Berg- und Hüttenmänische Monatshefte, 97, 41-51, Leoben.

Reyer, E. (1879): Tektonik der Granitergüsse von Neudeck und Karlsbad und Geschichte des Zinnbergbaues im Erzgebirge. - Jahrbuch d. geol. Reichsanstalt, 29, 3, 405-462, Wien.

Rojik, P. (2000): Historie cínového hornictví v západním Krušnohoří. Okresní muzeum a knihovna Sokolov, 233 pp.

Seltmann, R. - Stemprok, M. (1994): Textural evidence for the existence of two-phase granites in the Younger Intrusive Complex granites of the Krušné hory/Erzgebirge province. - Jour. Czech Geol. Soc., 39, 103-104, Praha.

Škvor, V. (1960): Poznámky k petrografii ložiska Přebuz v Krušných horách. - Věstník ÚUUG, 35, Praha.

Škvor, V. - Sattran, V. (eds.) (1974): Krušné hory - západní část. Soubor geologických map 1:50 000. - ÚÚG Praha. 
Šrámek, J. - Mrlina, J. (1997): Gravity field - its features and geological interpretation. In: Vrána, S. - Štědrá, V. (eds.): Geological model of western Bohemia related to the KTB borehole in Germany. - Journ. Geol. Sci., 47, 24-32, Praha.

Štemprok, M. (2003): The origin and mineralization of the tin-bearing granites of the Krušné hory (Erzgebirge) province: 3-D approach with new data on the ore deposit zoning around a granite batholith. - Global Tectonics and Metallogeny, 8, 1-4, 215-226, Stuttgart.

Vogel, J. (1872): Über den Zinnbergbau zu Neuhammer im böhmischen Erzgebirge. - MS Platten (Arch. ČGS P 2909/2).
Zoubek, V. (1951): Předběžná zpráva o geologickém výzkumu a mapování oblasti karlovarského plutonu. - Věst. Ústř. Úst. Geol., 24, 166-179, Praha.

- (1978): Tectonic control and structural evidence of the Krušné hory (Erzgebirge) tin-bearing pluton. - Metallisation associated with acid magmatism, Vol. 3, 57-76, Praha.

sine (ca. 1830): Geschichtliche Notizen über den Ursprung, die höchste Blüthe und den wieder allmähligen Verfall des Fribuser Zinnbergbaues. - MS (Arch. ČGS P 114).

\section{Cínová ložiska u Přebuzi a Rolavy v Krušných horách, Česká republika: klasické lokality, nové výzvy}

Nově byl studován pozdně variský karlovarský pluton v české části Krušných hor, s důrazem na greisenová ložiska cínu a jejich vztah k vysoce diferencovaným granitům. Autor vychází z vlastního podrobného terénního studia a výzkumu hornické historie. Nejdůležitější ložiska jsou ve studované oblasti seskupena zhruba do obvodu oválné struktury („,cínového kruhu“) přibližně uprostřed výchozu granitů mladšího intruzivního komplexu a prostorově se sdružují s nejmladšími vysoce vyvinutými granity. Greisenová pásma pronikají diskordantně všemi známými typy granitů a konvergují směrem do hloubky. Obsah cínu v nich ubývá rovněž s rostoucí hloubkou a laterálně směrem do středu „cínového kruhu“. Greisenové zóny jsou ve své ose doprovázeny slepými žilkami kasiteritu, löllingitu, mikroklinu, křemene a hematitu, které pokračují do zatím neznámých hloubek. Greiseny i žíly byly opakovaně tektonicky porušeny a mineralizovány. To vše podporuje výklad tektonické predispozice zrudnění a jeho hlubinného zdroje, který může být př́ibuzný se zdrojem pozdních intruzí vysoce diferencovaných granitů. Některé porfyrické granity ukazují zrnitostní bimodalitu základní hmoty, která může odpovídat texturám dvoufázových granitů utuhlých v subvulkanických podmínkách. Na prríkladech jsou dokumentovány různé typy rytmického páskování (stratifikace) granitů staršího i mladšího komplexu. 
